\title{
Approximation of the WRB reference group with the reapplication of archive soil databases
}

\author{
Dániel BALLA, ${ }^{1}$ Tibor József NOVÁK, ${ }^{2}$ Marianna ZICHAR ${ }^{3}$ \\ ${ }^{1}$ Department of Landscape Protection and Environmental Geography, \\ University of Debrecen, e-mail: balla.daniel@ science.unideb.hu \\ ${ }^{2}$ Department of Landscape Protection and Environmental Geography, \\ University of Debrecen, e-mail: novak.tibor@ science.unideb.hu \\ ${ }^{3}$ Department of Computer Graphics and Image Processing, \\ University of Debrecen, e-mail: zichar.marianna@inf.unideb.hu
}

Manuscript received Aug. 15, 2016; revised Aug. 30, 2016; Accepted Sept.1, 2016

\begin{abstract}
In our study, we tested the existing and freely accessible soil databases covering a smaller geographical region surveyed and classified according to the Hungarian classification in order to approximate the WRB soil reference groups (RSG). We tested the results and applicability of approximation for the RSG with three different methods on 12 soil profiles. First, RSGs were assigned to Hungarian soil taxa based on results of previous correlation studies, secondly, a freely accessible online database of ISRIC was applied furthermore, and an automated reclassification developed and programmed by us was used, which takes the original soil data as input.
\end{abstract}

Keywords: soil classification, Solonetz, Vertisol, WRB correlation, WRB algorithmization

\section{Introduction}

As a result of the soil survey works during the past 100 years in Hungary, there are enormous amounts of soil data available for meta-analyses. However, due to their different approaches of soil profile description and laboratory methods, it is often difficult to imply them for present-day application in researches with novel approaches. Furthermore, because of the limited options and financial resources, the requirement for the reuse, reclassification, and harmonization of these data with later databases is constantly increasing [1]. Several difficulties emerge in this 
process since these data are based on different methodology and classification systems.

Currently, the most commonly used soil classification system in Europe is based on the diagnostic approach of World Reference Base for Soil Resources (WRB). It provides well-defined terminology and quantifiable conditions [2]. During the recent years, numerous results were published regarding the mapping of soil databases converted from different sources into WRB [3-10] and the classification of soils with simplified automated algorithms [11].

Láng et al. $(2010,2013)$ used the taxonomical-distance-based comparison to perform the numerically controlled harmonization of the Hungarian soil classification with the WRB. In their study, they investigated the correlation possibilities between the national and the WRB classification in the case of brown forest soils (cca. Luvisols, according to WRB), using the method for classification purposes for the first time. Based on their results, the numeric comparison of the Hungarian soil types to the similar units of WRB became possible [12-13].

The differences and connections between WRB and the Hungarian soil classification were first summarized by Michéli et al. (2006) and Krasilnikov et al. (2009) who also established correlation keys which are primarily based on field experiences and the definitions of the classification units [14].

This study investigates data of soil profiles from an area which was previously mapped and classified based on the Hungarian classification system in order to identify whether it is possible to classify the soil profiles characterized by the archive data according to WRB and, if it is, to define the degree of accuracy. The comparison was used to answer the question if we can only acquire the data recorded according to the different methodology and taxonomy, whether the (unambiguously inaccurate and in some cases impossible) reclassification using the data ill-suited to WRB could provide more accurate identification of RSGs than the automatic assigning based on the system-level correlation or the acceptance of the RSG predicted by the ISRIC database. Since data about the taxonomical status of soils assigned properly to WRB in field are available in low spatial density, approximation could be useful in WRB soil mapping and reapplication of archive data as well.

\section{Study area}

The investigated profiles are located on the Hortobágy, Dél-Hajdúság, and Nagy-Sárrét regions in Eastern Hungary (Fig. 1). Hortobágy is an abandoned alluvial plain. It is the largest continuous area with alkaline soils on the continent. Approximately $3 / 4$ of the area is covered by alkaline and in deeper soil horizons 
also by salt-affected soils. As a consequence of shallow alkaline groundwater, diverse alkaline soil complexes were formed on the silty loess deposits with characteristical mosaic spatial pattern [15].

Dél-Hajdúság is a fossil alluvial plain covered by silty loess. In lower topographic positions, alkaline meadow chernozem soils can be found with significant clay content, which are used predominantly as croplands, but in smaller extent also pastures or forests. At higher elevations, more fertile typical carbonatic chernozem soils are dominant. Alkaline and salt-affected soils are just in subordinate extent in this landscape, which has great importance from agricultural point of view [16].

Nagy-Sárrét is a recent alluvial plain interspersed with alkaline lands and flood-free areas. Part of it has basin-like characteristics, where in the deeper, artificially drained areas dominantly croplands and in small fragments natural grassland vegetation can be found. All soils of the landscape have been developed under influence of shallow groundwater and partially of temporary surface water cover, which is reflecting in topsoil, but more frequently in the subsoil properties. As a result of anthropogenic activities, these soils are mostly artificially drained, which is expressed in the lowering of groundwater level and the retreat of surface water cover [17].

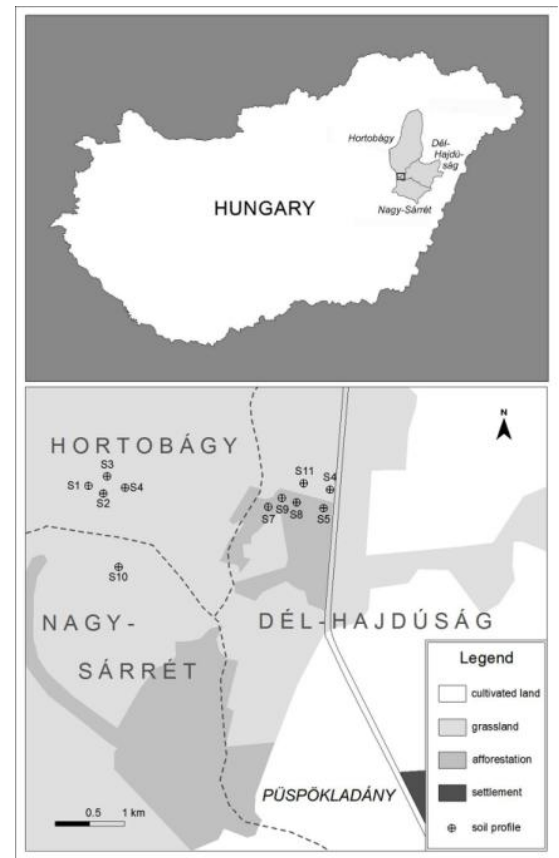

Figure 1. Location of the study area and the sampling sites in Hungary 


\section{Materials and methods}

Twelve soil profiles (S1-S12), 1 on the Nagy-Sárrét, 4 on the Hortobágy, and 7 on the Dél-Hajdúság, were investigated (Fig. 1). The profiles represents the spatial variability of soils within the three neighbouring regions [18]. The preparation, analysis, and classification according to the Hungarian taxonomy of the profiles took place between 1999 and 2002. To compare the results and applicability, three methods for the approximation of WRB RSGs were used (Table 1): 1) assigning the profiles to WRB according the correlation databases between WRB and Hungarian classification's soil taxa, 2) prediction of RSGs based on ISRIC database, and 3) results of automatized WRB classification and the prediction of RSGs. In the first case, we assign to the profiles two or more RSGs. These were given as possible equivalents according to the correlation table (Michéli et al. 2006) [11]. In the second case, we used the coordinates of profiles in order to predict the RSG using the ISRIC web services [19-20]. These methods we used to associate the profiles with RSGs and give the probabilities that the database stored in each location. In the third case, we carried out the reclassification based on the available data from the soil profiles with automated algorithms which were designed in accordance with the WRB diagnostics.

Table 1. Overview of the input and output data of the three applied methods for the approximation of WRB RSG

\begin{tabular}{|l|l|l|}
\hline \multicolumn{1}{|c|}{ Approximation method } & \multicolumn{1}{c|}{ Input data } & \multicolumn{1}{c|}{ Output data } \\
\hline $\begin{array}{l}\text { System-level correlation between } \\
\text { Hungarian and WRB soil taxa }\end{array}$ & Hungarian soil type & WRB RSG(s) one or more \\
\hline $\begin{array}{l}\text { Prediction of RSGs based on ISRIC } \\
\text { database }\end{array}$ & Coordinates of the location & $\begin{array}{l}\text { WRB RSG(s), several, each with } \\
\text { probability (\%) of occurence }\end{array}$ \\
\hline $\begin{array}{l}\text { Automatized reclassification according } \\
\text { to WRB-based algorithms }\end{array}$ & $\begin{array}{l}\text { Soil horizon data from } \\
\text { profiles }\end{array}$ & $\begin{array}{l}\text { WRB RSG, one only in case it } \\
\text { fits entirely }\end{array}$ \\
\hline
\end{tabular}

\section{Possibilities and uncertainties of automatized classification}

The possibilities for reclassification of soil data acquired from different sources are limited for a number of reasons. Basically, missing data or the sampling method can be the reason why a given soil profile cannot be classified and assessed with an adequate degree. The automatable method suggested by Eberhardt and Waltner (2010) is different from the previous ones, being primarily the correlation and harmonization of existing soil taxa [5]. The essence of the suggested method is using the original soil survey data to identify the WRB units instead of harmonizing each national classification unit. This requires to design the 
necessary algorithms separately for every database applying different methodologies [11]. But this is rather time consuming and errors occurring due to the different methods can be corrected only to a limited degree. Nevertheless, after the initial setup of the system, a practically unlimited amount of soil units can be classified automatically; therefore, it makes possible the process of large databases.

\section{Automatization of the classification process}

The specification is a development of a plug-in, which is able to classify soils based on the archive data in accordance with the WRB. As a preparatory step, our soil data need to be integrated into a processable data structure [21]. Therefore, it is advisable to store the data in relational data tables so that the later processes can be automatized more easily [22]. The first table includes field and laboratory results and further computed data such as diagnostic levels, attributes, and soil materials [23]. The second table records the geographical location of the soil profiles and the result of the classification.

The next phase of the work is the algorithmization of the level verifying, attribute calculating, and the main group's specifying components. Since the WRB classification system has fixed criteria and in most cases the archive data do not follow the structure of the idealized system, the method of this process also has to be taken into account.

\section{Decision process of soil RSG}

Since the heavily textured soils with high clay content usually form a separate WRB RSG, which directly follows the Solonetz soils in the WRB (2014) system, we assumed that some of them belong to either the Solonetz or the Vertisol reference groups based on the available data, references, soil maps, and the topographic characteristics of the profiles. In order to reach this conclusion, the possibility of belonging to one of the previous five groups had to be excluded (Fig. 2).

The classification as Histosol group could be excluded since our profiles do not have organic soil material $\left(>20 \% \mathrm{C}_{\text {org }}\right.$ ):

1. at least $10 \mathrm{~cm}$ thick if it starts at the surface and the soil climate is cryic or pergelic, or the underneath soil level is coherent rock, technical solid material, or rough debris the cracks of which are filled with organic material, or

2. at least $60 \mathrm{~cm}$ thick for $100 \mathrm{~cm}$ from the surface, if it starts within $40 \mathrm{~cm}$ from the surface and at least $75 \%$ of its volume is made up of fibrous peat moss, or

3. at least $40 \mathrm{~cm}$ thick for $100 \mathrm{~cm}$ from the surface, if it starts within $40 \mathrm{~cm}$ from the surface, if it is made up of other material. 
The classification can be keyed out at Anthrosols if the soil does not have a horizon of $\geq 50 \mathrm{~cm}$ thickness which is ploughed, cultivated, or changed due to irrigation (hortic, irragric, terric).

The classification keys out at Technosols if in the top $100 \mathrm{~cm}$ layer of the soil the amount of artefacts does not reach $20 \%$ by volume or there is no technic hard material or artificially established impermeable geomembrane. Since the examined databases are originated from cultivated or pasture sites, this RSG can be excluded in the case of all the investigated profiles.

Cryosols can be excluded in the examined geographical region due to the different soil climate (they do not have cryic horizon), because this RSG cannot be found under the Hungarian climate conditions.

The classification as Leptosol can be excluded if in the soil:

1. there are no continuous hard rock or technic hard material within $25 \mathrm{~cm}$ starting from the surface, or

2. within $75 \mathrm{~cm}$ starting from the surface, or if the soil is shallower, down to the surface of the continuous hard rock or technic hard material the fine earth part makes up $\geq 20 \%$ by volume of the entire soil.

3. The parent materials of the study area are unconsolidated sediments, where rough debris or technical solid material can be found only under urbanized conditions due to anthropogenic influence. In this case, however, the soils could be keyed out among Technosols, therefore this RSG could be excluded as well based on the land-use characteristics of the investigated area.

The soil can be classified as Solonetz if it has a natric horizon within $100 \mathrm{~cm}$ starting from the surface, and cannot be classified into any of the previous RSGs. If this condition is met, the investigated profile keys out into Solonetz. The next step of the process is the identification of the natric horizon if it presents.

The soil can be classified as Vertisol if

1. it has a vertic horizon starting within $100 \mathrm{~cm}$ from the surface and

2. if the vertic horizon does not start at the surface, the clay content is $\geq 30 \%$ throughout between the surface and the vertic horizon,

3. the surface is articulated by seasonally opening-closing shrink-swell cracks.

Therefore, in order to decide whether the soil belongs to the Vertisol, not only the proving of the vertic horizon was necessary but the clay content above the vertic horizon (if present) and the presence of cracks within the horizon should also be checked. If based on the established criteria, the investigated profile cannot be assigned to any of these RSG-s; the RSG of the profile will be considered as unknown. 

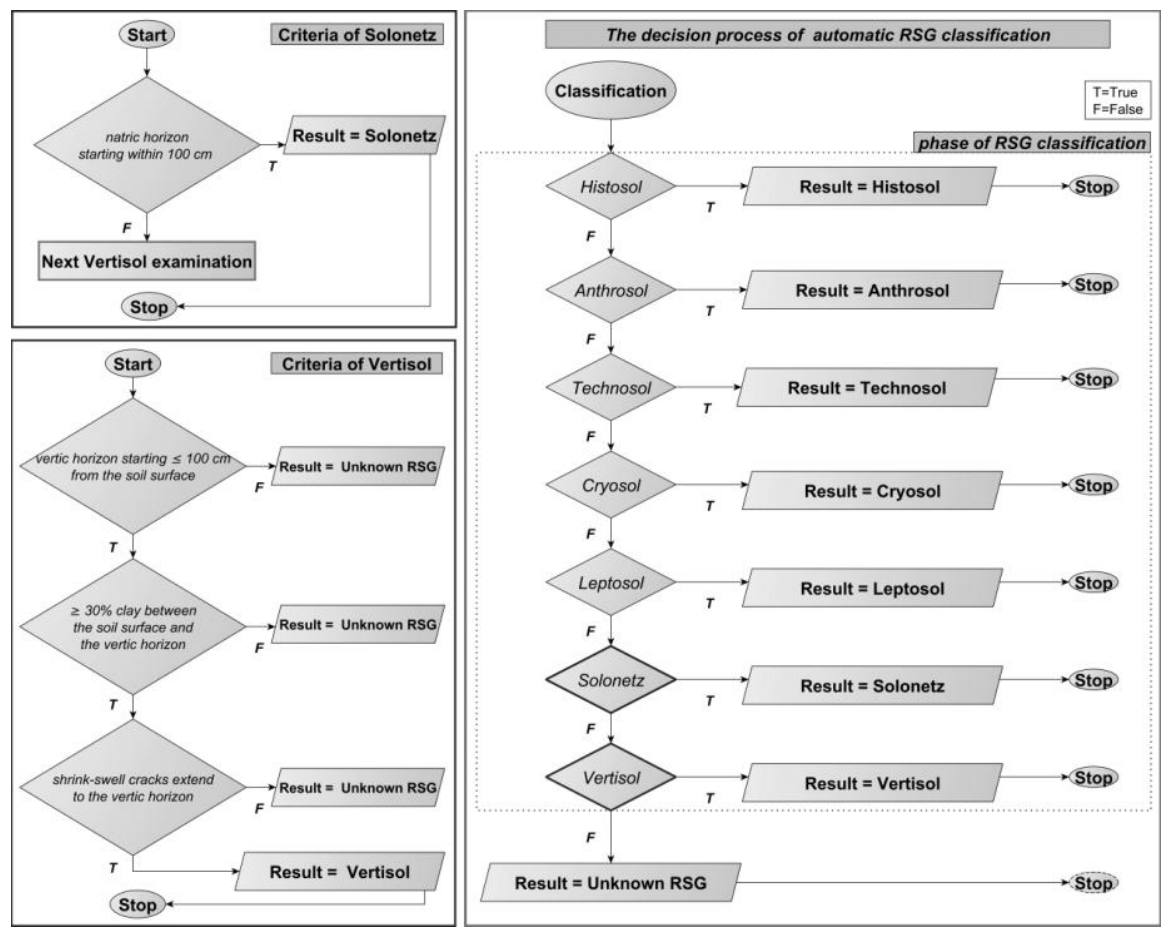

Figure 2. The process of automatic soil classification.

\section{Results and discussions}

The profiles were classified as meadow solonetz (S1, S2, S3, S4, S10, S11, and S12), typical meadow soil (S5, S9), meadow chernozem (S7), and solonetzic meadow soil (S6, S8) categories according to the Hungarian classification system (Table 2). Due to the correlation project, the result of the classification could be compared to the results published by Michéli et al. (2006). The following RSGs were established for the types identified by us according to the Hungarian taxonomy: meadow solonetz-Solonetz, Vertisol; typical meadow soil - Phaeozem, Chernozem; Vertisol; meadow chernozem - Chernozem, and solonetzic meadow soil - Vertisol, Cambisol.

The estimation of RSG based on the ISRIC database provides more information as far as the probability of RSGs associated with a given location is also predicted nevertheless, these data can be considered only as an approximation.

The last column of Table 2 includes the RSG as results of the automatized classification carried out by the software developed by us. Five profiles were classified as Solonetz, 4 were classified as Vertisol, and 3 were considered as RSG unknown. In the case of profiles which were considered as belonging to unknown 
RSG, the available data were not sufficient for the automated classification, or the profile could not even provisionally be classified into any of the RSGs, because the classification requirements were not met. In the first case, the missing ESP (Exchangeable Sodium Percentage) values of S1 and S2 excluded them being classified as Solonetz. In the case of S7, either the available data were not sufficient or it was placed behind the Vertisol in the WRB system, and in this study we have not dealt with the classification of those RSGs.

Table 2. Soil type (Hungarian classification) and identification of RSGs based on systemlevel correlation (Michéli et al. 2006), soil map data based on approach (ISRIC), and soil profile data based on automatized reclassification

\begin{tabular}{|c|l|l|l|l|}
\hline $\begin{array}{c}\text { Profile } \\
\text { ID }\end{array}$ & Hungarian soil type & $\begin{array}{c}\text { Results of Michéli et al. } \\
(\mathbf{2 0 0 6 )} \text { correlation }\end{array}$ & $\begin{array}{c}\text { RSG } \\
\text { according to } \\
\text { automatic } \\
\text { classification }\end{array}$ \\
\hline S1 & meadow solonetz & Solonetz/Vertisol & Solonchak (18\%), Solonetz (14\%), Vertisol (12\%) & Unknown \\
\hline S2 & meadow solonetz & Solonetz/Vertisol & Solonchak (18\%), Solonetz (14\%), Vertisol (12\%) & Unknown \\
\hline S3 & meadow solonetz & Solonetz/Vertisol & Solonchak (18\%), Solonetz (14\%), Vertisol (12\%) & Solonetz \\
\hline S4 & meadow solonetz & Solonetz/Vertisol & Solonchak (18\%), Solonetz (14\%), Vertisol (12\%) & Solonetz \\
\hline S5 & typical meadow soil & Phaeozem/Chernorem/Vertisol & Vertisol (17\%), Solonchak (13\%), Solonetz (12\%) & Vertisol \\
\hline S6 & solonetzic meadow soil & Vertisol/Cambisol & Vertisol (17\%), Solonchak (13\%), Solonetz (12\%) & Vertisol \\
\hline S7 & meadow chernozem & Chernozem & Solonetz (13\%), Solonchak (13\%), Vertisol (10\%) & Unknown \\
\hline S8 & solonetzic meadow soil & Vertisol/Cambisol & Vertisol (17\%), Solonchak (13\%), Solonetz (12\%) & Vertisol \\
\hline S9 & typical meadow soil & Phaeozem/Chernorem/Vertisol & Solonchak (19\%), Solonetz (17\%), Vertisol (11\%) & Vertisol \\
\hline S10 & meadow solonetz & Solonetz/Vertisol & Solonchak (19\%), Solonetz (14\%), Vertisol (9\%) & Solonetz \\
\hline S11 & meadow solonetz & Solonetz/Vertisol & Vertisol (17\%), Solonchak (13\%), Solonetz (12\%) & Solonetz \\
\hline S12 & meadow solonetz & Solonetz/Vertisol & Unknown coordinates & Solonetz \\
\hline
\end{tabular}

Based on the results, it can be seen that in some cases the archive soil data sources do not contain sufficient information to identify unambiguously the diagnostic horizons of the profiles according to WRB. In accordance with the methodology of WRB, this excludes the classification of soil profiles according to WRB since it requires the information about the present diagnostic horizons to assign or exclude any RSGs; therefore, the result of the automated classification led to unknown result. The vertical position of identified diagnostic horizons in the studied 12 profiles based on the available data are presented in Figure 3. Because of the lack of data, not only the positive identification of certain horizons are difficult but also frequently the exclusion of them (Table 3).

In some cases, the specific data types were not available, and there were other soil data (categorical or derived data) based on the given feature (e.g. surface cover, soil moisture household, and soil climate type) that could be inferred (however not in a numerical way). For example, the presence of shrink-swell cracks is a diagnostic criteria to identify vertic horizon, but earlier databases do not contain information concerning that, with the exception of mentioning deep, wide cracks at the description of structure. The most frequent problem out of the ones 
associated with the data was the limited number of data regarding depth. The established database managed some of its data with a topsoil/subsoil distinction, which in a lot of cases makes it more difficult or excludes entirely the possibility of precise examining of the depth criteria according to the WRB. Since the data collection and the division of the profiles to horizons were not carried out in accordance with the guidelines of WRB, the indication of diagnostic horizons conforms to the sampled layers and is not necessarily in accordance with the boundaries of diagnostic horizons which could be observed and identified in the field.

The applied three methods to estimate WRB RSGs lead to different results. In the case of the classification based on types of the Hungarian taxonomy applying the results of former correlation studies, there was not possible to assign to just one RSG, but two, or even three RSGs were given as possible equivalents, without estimation of probability. Therefore, the unambiguous reference group identification is not possible in this way. The approximation of RSG using the ISRIC database is more useful because the probabilities of possible RSG-s were associated to a given profile. The spatial resolution of this database, however, is not adequate to precisely describe the heterogeneity of the area. Based on the coordinates of the investigated profiles, the ISRIC database predicted Solonchak and Solonetz RSGs. In addition, in one case, RSG prediction was not possible due to missing coordinates. In the case of automated data classification, five profiles were classified as Solonetz, four as Vertisol, and three were keyed out as RSG unknown or impossible to predict due to missing data. The most relevant question in our study - in addition to missing data - was the uncertainity of identification of diagnostic horizons (natric, vertic, calcic, and mollic) based on the archive data. Since the data collections were not carried out in accordance with the guidelines of WRB, the indication of diagnostic horizons conforms to the sampled layers (diagnostic horizons calculated from the layers), which are not definitely in accordance with the boundaries of horizons which can be identified in the field, therefore it can only serve as a basis for the identification. However, regarding the assessment and application of decision-making rules of the established RSGs, it should be noted that these only mean a "best approximation" for the studied archive soil data and do not substitute the field data collection, description, and classification process according to the detailed WRB methodology. 


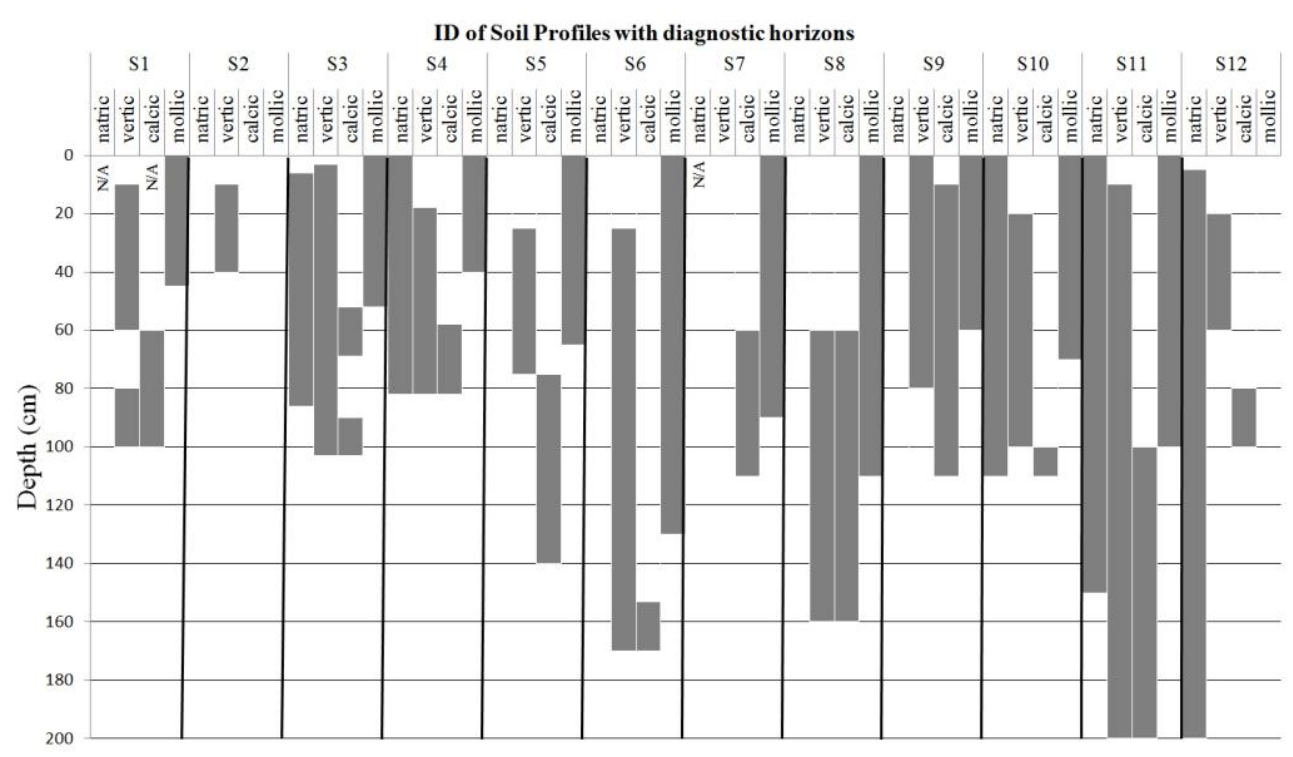

Figure 3. Data based on the estimation of diagnostic horizons in investigated profiles

Table 3. Soil characteristics of the profiles representing the most typical soil conditions within the study area (S7-S9-S11)

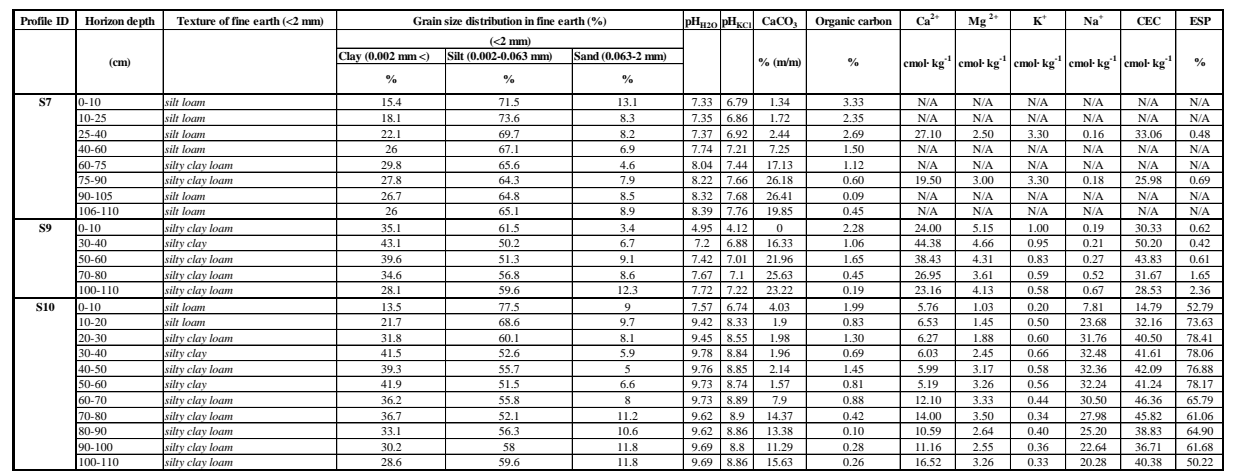

The results of reclassification also highlight the fact that the types/main types of the Hungarian soil classification system and the reference groups of WRB system cannot be completely corresponded to each other. However, until data collected by the WRB methodology are not available in large number and with 
adequate spatial frequency, the estimation carried out by the reclassification of archive data provides a good alternative for the field identification of WRB RSGs.

\section{Conclusion}

Using the automated WRB soil classification based on our own developed algorithms, five profiles could be classified as Solonetz, four as Vertisol, and the remaining three profiles were keyed out as unknown reference soil group from the 12 investigated profiles. According to the correlation studies, the types of the Hungarian taxonomy could be assigned not to one but sometimes to three RSGs with unknown probability. This did not allow the unambiguous reference-grouplevel WRB classification based on the archived soil data. The approximation carried out with the help of ISRIC database also indicates more than one RSGs associated with a distinct location, but it predicts the probability of their occurrence. However, the spatial resolution is not adequate to draw an accurate map of the heterogeneity of soils. In the case of the proved profiles, Vertisol, Solonchak, and Solonetz RSG-s could be identified.

The results of the automatized reclassification of the archive data suggested that the RSG-s of WRB cannot be unambiguously approximated as a consequence of the different field-surveying approaches and methods. The different data collection structure strongly limits the reclassification possibilities as well, but at least it provides more accurate results compared with the estimation of the RSGs by simple assigning according to general correlation rules or prediction based on location and ISRIC database.

\section{References}

[1] Dobos, E. (2006), The future of soil science: a vision from Europe. In: Hartemink, A. E., (ed.), The future of soil science. IUSS. Wageningen, 34-37.

[2] IUSS Working Group WRB (2014), World Reference Base For Soil Resources. International soil classification system for naming soils and creating legends for soil maps ( $\left.3^{\text {rd }} \mathrm{ed}.\right)$. Rome: FAO.

[3] Fehér, O., Füleky, Gy., Madarász, B., Kertész, Á. (2006), Morphological and diagnostic properties of seven volcanic soil profiles according to the Hungarian Soil Classification and the World Reference Base for Soil Resources (WRB, 1998). Agrochemistry and Soil Science. 55(2), 347-366.

[4] Barta, K., Tanács, E., Samu, A., Keveiné, B. I. (2009), Classification of Hungarian rendzina soils in conformity with the international World Soil Reference Base System (WRB). Agrochemistry and Soil Science 58(1), 7-18.

[5] Eberhardt, E., Waltner, I. (2010), Finding a way through the maze - WRB classification with descriptive data. In: Gilkes J. R., Prakongkep N. (eds), Soil solutions for a changing world: Proceedings of the $19^{\text {th }}$ World Congress of Soil Science: 1-6 August 2010, Brisbane, Australia. International Union of Soil Sciences, 5-8.

[6] Pásztor, L., Szabó, J., Bakacsi, Zs. (2010), Digital processing and upgrading of legacy data 
collected during the 1:25 000 scale Kreybig soil survey. Acta Geodaetica et Geophysica Hungarica 45, 127-136.

[7] Shi, X. Z., Yu, D. S., Xu, S. X., Warner, E. D., Wang, H. J, Sun, W. X., Zhao, Y. C., Gong, Z. T. (2010), Cross-reference for relating Genetic Soil Classification of China with WRB at different scales. Geoderma 155, 344-350.

[8] Zádorová, T., Penížek, V. (2011), Problems in correlation of Czech national soil classification and World Reference Base 2006. Geoderma 167-168, 54-60.

[9] Pásztor, L., Szabó, J., Bakacsi, Zs., Laborczi, A. (2013), Elaboration and applications of spatial soil information systems and digital soil mapping at Research Institute for Soil Science and Agricultural Chemistry of the Hungarian Academy of Sciences. Geocarto International 28(1), 13-27.

[10] Huyssteen, C. W., Michéli, E., Fuchs, M., Waltner, I. (2014), Taxonomic distance between South African diagnostic horizons and the World Reference Base diagnostics. Catena 113, 276-280.

[11] Michéli, E., Fuchs, M., Hegymegi, P., Stefanovits, P. (2006), Classification of the major soils of Hungary and their correlation with the World Reference Base for Soil Resources (WRB). Agrochemistry and Soil Science 55(1), 19-28.

[12] Láng, V., Fuchs, M., Waltner, I., Michéli, E. (2010), Taxonomic distance measurements applied for soil correlation. Agrochemistry and Soil Science. 59(1), 57-64.

[13] Láng, V., Fuchs, M., Waltner, I., Michéli, E. (2013), Soil taxonomic distance, a tool for correlation: As exemplified by the Hungarian brown forest soils and related WRB Reference Soil Groups. Geoderma 192, 269-276.

[14] Krasilnikov, P., Arnold, R., Michéli, E. (2009), Soil classification of Hungary. In: Krasilnikov, P., Ibáñez, Martí, J.-J., Arnold, R., Shoba, S. (eds), A Handbook of soil terminology, correlation and classification. London, Sterling, VA: Earthscan, 170-175.

[15] Tóth, Cs., Novák, T., Rakonczai, J. (2015), Hortobágy Puszta: Microtopography of alkali flats. In: Lóczy, D. (ed.), Landscapes and landforms of Hungary. Springer Verlag, 237-247.

[16] Dövényi, Z. (2010), Inventory of microregions in Hungary. Geographical Research Institute, Budapest.

[17] Várallyay, Gy. (1972), Hydraulic conductivity of salt affected soils in the Hungarian Plain. Agrochemistry and Soil Science 21(1-2), 57-81.

[18] Novák, T. (2005), Tájváltozások értékelése szikes mintaterületen a talajok és a vegetáció egyes jellemzői alapján [Evaluation of landscape changes of a sample area in the Hortobágy based on soil and vegetation characteristics], PhD thesis. University of Debrecen, Faculty of Sciences, Department of Landscape Protection and Environmental Geography, Debrecen.

[19] Hengl, T., de Jesus, J. M., MacMillan, R. A., Batjes, N. H., Heuvelink, G. B., Ribeiro, E., Samuel-Rosa, A., Kempen, B., Leenaars, J. G. B., Walsh, M. G., Gonzalez, M. R. (2014), SoilGrids $1 \mathrm{~km}$ - global soil information based on automated mapping. PLoS One 9(8).

[20] ISRIC - World Soil Information (2019): SoilGrids: an automated system for global soil mapping. Available for download at: http://soilgrids $1 \mathrm{~km}$.isric.org.

[21] Nelson, M. A., Odeh, I. O. A. (2009), Digital soil class mapping using legacy soil profile data: a comparison of a genetic algorithm and classification tree approach. Australian Journal of Soil Research 47, 632-649.

[22] Dobos, E., Hengl, T. (2009), Soil mapping applications. In: Hengl T., Reuter H. I. (eds), Geomorphometry - concepts, software, applications [Developments in Soil Science 33] Elsevier, 461-479.

[23] Food \& Agriculture Org. of the United Nations (2006), Guidelines for soil description. Fourth edition, Rome. FAO. 